\title{
The Effect of Transformational Leadership Style toward Lecturers Performance on Faculty of Economics of Makassar State University
}

\author{
${ }^{1}$ Anwar Ramli, ${ }^{2}$ Nursia, ${ }^{3}$ Asniwati \\ ${ }^{1}$ Department of Management, Faculty of Economy, State University of Makassar, South \\ Sulawesi, Indonesia \\ ${ }^{2}$ The Lecturer of Department of Management Program STIMI-YAPMIM Makassar, South- \\ Indonesia \\ ${ }^{3}$ The Head of Department of Management Program STIMI-YAPMIM Makassar South- Sulawesi, \\ Indonesia
}

\begin{abstract}
The purpose of this study is to determine the effect of transformational leadership style toward the performance of lecturers, especially in the Faculty of Economics, State University of Makassar.

The method used in data collection is survey method, namely by dividing the questionnaire to the entire population of 62 people. In addition, the data also obtained through some documentation from the administration of Faculty of Economics, State University of Makassar. Further data that has been obtained by using Likert scale, processed with the help of SPSS program.
\end{abstract}

The results showed that by applying the transformational leadership style greatly affect the performance of lecturers, especially in the Faculty of Economics, State University of Makassar.

Keywords: Transformational Leadership Style, lecturer performance

\section{INTRODUCTION}

Faculty of Economics Makassar State University is an educational institution that plays a direct role in produce the intellectuals who will become the leader of the nation in the future. Lecturer is one of the components that determine the quality of an alumnus in an educational institution. Therefore the performance of lecturers is required to continue to be improved along with the development of science and technology which is marked by the globalization era which we are now experiencing. Lecturers must implement Three Obligation of High Institution, which includes education and teaching, research, and community service.

In implementing the obligation of education and teaching, a lecturer must perform with the ability and expertise that qualified so that the students who are taught are expected to have cognitive aspects that are also qualified. Furthermore, lecturers are also required to conduct research whose output is expected to be a reference or input for stakeholders. Then the obligation of dedication to the community is certainly absolute for a lecturer which is an implication of the level of intellectuality that is owned by a lecturer at a college institution.

However for to have the ability to implement Three obligation of High Institution, there are factors that affect the performance of a lecturer that is the leadership factor in the institution concerned. One of the known leadership styles is the transformational leadership style which is the subject of this research relating to the performance of a lecturer at the Faculty of Economics, Makassar State Universty, and Indonesia. The transformational leadership style is the ability to influence a relationship that tends to follow certain patterns / strategies for the achievement of common goals. Bass (1985, in Wutun, 2001, p.345).

The transformational leadership style is a leadership model for improving measurable human performance, with indicators of trust, admiration, loyalty, and respect for leaders, to do something more and do it beyond their own expectations (Bass, 1994). One of the concepts of leadership that can 
explain precisely the behavioral patterns of real superior leadership and be able to contain behavioral patterns from other leadership theories is transformational leadership, Wutun (2001, p.345).

The transformational leadership style has four behavioral components, namely:

a. Idealized Influence is the behavior of a transformational leader who has strong self-belief, always present in difficult times, uphold moral values, cultivates pride in his followers, whose vision is clear, and his steps always have a definite purpose, and that his subordinates willingly follow him, he places himself as a model for his subordinates.

b. Individualized Consideration, is the behavior of a transformational leader, in which he reflects, thinks, and always identifies the needs of his subordinates, tries his best to recognize the employee's abilities, encourages his employees to learn, provides the widest possible learning opportunity, always hears his subordinates Attention, and for him is the key to the success of a work.

c. Inspirational Motivation is the transformational leader's effort to inspire his followers to achieve unimaginable possibilities, challenging subordinates to high standards.

d. Intellectual Stimulation. Imagination combined with intuition but guarded by logic used by this leader in inviting subordinates to be creative. (Bass and Avolio 1990).

Then, according to (Wutun (2001, p.353) transformational leadership has five aspects:

1. Atributed Charisma: a charismatic leader demonstrates his vision, skillful abilities and actions that take the interests of the organization and the interests of others rather than personal interests.

2. Idealized Influence: leaders try to influence subordinates by direct communication by emphasizing the importance of values, commitment and belief, and have a determination to achieve goals while keeping in mind the moral and ethical consequences of each decision making..

3. Inspirational Motivation: leaders act by motivating and inspiring subordinates through the giving of meaning, participation and challenge to the duties of subordinates.

4. Intellectual Stimulation: leaders try to encourage subordinates to rethink work and seek new ways of working to accomplish their tasks.

5. Individualized Consideration: leaders try to give attention to subordinates as closely as possible so that subordinates feel cared for by their boss.

Furthermore, performance is a real behavior that everyone displays as work performance generated by employees in accordance with its role in the company. (Veizal Rivai 2004: 309). Then Robert L. Mathis and John H. Jackson Jimmy Sadeli and Bayu Prawira (2001: 78): states that performance is basically what employees do or do not do. According to John Witmore in Coaching for Perfomance (1997: 104) performance is the execution of the functions demanded of a person or an action, an achievement, a general exhibition of skills.

Based on the above description, it can be argued that the main problem in this research is how much influence the transformasinal leadership style towards the performance of lecturers at the Faculty of Economics Makassar State University (FE-UNM). The main purpose of this study is to find out how much influence the leadership style of transformation toward the performance of lecturers in FEUNM.

\section{METHOD}

\subsection{Population and Data Collection Techniques}

In this research data collection method used survey method, ie by spreading the questionnaire to the entire population that is all the lecturers in FE-UNM totaling 62 people.

\subsection{Operational Definition and Variable Measurement}

a. The Transformational (transformational leadership) (X) style is meaningful to transform or transform something into another different form. A transgformational leader must be able to transform optimally the organization's resources in order to achieve meaningful goals in accordance with predetermined targets. Resources can be in the form of Human Resources (HR), Facilities, funds, and external factors organization. In the educational institutions (faculty) of human resources are the Dean, Vice Dean, Head of Study Program, lecturers, subordinate staff and students. 
b. Performance Lecturer ( $\mathrm{Y}$ ) is Lecturer Performance is the success of a lecturer in completing the main tasks. Lecturer's performance is what influences how much they contribute to the institution they oversee, out put quality, out put period, workplace presence and cooperative attitude.

\subsection{Measurement of Variables}

According Sugiyono (2001: 69), Measurements are a set of rules needed to quantitative data from the measurement of a variable.

Table1. Research Variables and Indicators

\begin{tabular}{|c|l|ll|}
\hline $\mathrm{Nu}$ & \multicolumn{1}{|c|}{ Variable } & Indicator \\
\hline 1 & Transformational Leadership Style (X): & 1. & Ideal effect \\
& & 2. & Individual considerations \\
& & 3. & Inspirational motivation \\
& & 4. & Intellectual stimulation \\
\hline 2 & Lecturer Performance (Y): & 5. & Charisma \\
& & 1. & Commitment \\
& & 2. & Efficiency \\
& & 3. & Discipline \\
& & 4. & Initiative \\
\hline
\end{tabular}

Source: Bass \& Avolio (1999)

\subsection{Data Analysis Technique}

Variable measurement tool used in this research is with Likert Scale. Furthermore, data analysis techniques used simple linear regression with the formulation as follows:

$\mathrm{Y}=\mathrm{a}+\mathrm{bX}$ (Riduwan, 2010: 97).

Where:

$\mathrm{Y}=$ Performance of FE-UNM lecturers

$\mathrm{X}=$ Transformational leadership style

$\mathrm{a}=$ Constants

$\mathrm{b}=$ regression coefficient

Ho: The independent variable (transformational leadership style) has no significant effect on the dependent variable (lecturer performance).

Ha: The independent variable (transformational leadership style) has a significant influence on the dependent variable (lecturer performance).

The basis for decision making (Ghozali, 2005: 84) is to use the probability numbers of significance, namely:

- If the probability number is significant $>0.05$, then Ho is accepted and Ha is rejected.

- If the probability number of significance $<0.05$, then Ho is rejected and Ha accepted.

\section{RESULTS}

Respondents in this research used a sample of 62 lecturers at the Faculty of Economics, Makassar State Univesity. There are 4 characteristics of respondents included in this study, which is based on age, gender, employment and education. To clarify the characteristics of respondents in question, then presented table on respondents as follows:

a. Age

Table2. Percentage of respondents by age

\begin{tabular}{|c|c|c|}
\hline Age (years old) & Frequency (people) & Percentage (\%) \\
\hline $30-40$ & 13 & 20 \\
\hline $41-50$ & 19 & 31 \\
\hline $51>$ & 30 & 49 \\
\hline Amount & 62 & 100 \\
\hline
\end{tabular}

Source: Primary Data processed in 2017 
Based on the data in table 1, the table shows that of 62 lecturers who were sampled in the study, dominated by respondents aged 51> years old ie 30 people or $49 \%$. This shows the age of $51>$ years old is a productive age to work, while the smallest frequency of respondents is the age of 30-40 years old as many as 13 people where the age is mostly new lecturers. So it can be concluded that most lecturers of the Faculty of Economics, State University of Makassar is a lecturer who is 50 years old.

\section{b. Gender}

Table2. Percentage of respondents by Gender

\begin{tabular}{|c|c|c|}
\hline Gender & Frequency (people) & Percentage (\%) \\
\hline Man & 46 & 75 \\
\hline Women & 16 & 25 \\
\hline Amount & 62 & 100 \\
\hline
\end{tabular}

Source: Primary Data processed in 2017

Based on the data in table 2, the description of the respondent's profile on the table based on gender shows that the respondents of male sex of 46 people or $75 \%$ and the female sex of 16 people or $25 \%$. Differences from the sex is very much different as much as 30 people. This shows that the lecturer at the Faculty of Economics Makassar State University is dominated by male lecturers.

\section{c. Years of Service}

Table3. Percentage of respondents by years of service

\begin{tabular}{|c|c|c|}
\hline Years of Service & Frequency (people) & Percentage (\%) \\
\hline $0-5$ & 4 & 6 \\
\hline $6-10$ & 20 & 62 \\
\hline$>11$ & 38 & 100 \\
\hline Amount & 62 & 62 \\
\hline
\end{tabular}

Source: Primary Data processed in 2017

Based on the data in table 3, the table shows the profile description of respondents based on the period of work, ie from 62 samples in the study, 38 people or $62 \%$ have worked for 11 years and above and lecturers who have worked for 6-10 years as many as 20 people or $32 \%$, then the new work for $0-5$ years as many as 4 people or $6 \%$ due to the acceptance of new lecturers every year. This shows that most of the lecturers of Faculty of Economics UNM have been working for 11 years and above.

\section{d. Last Education}

Table4. Percentage of respondents by recent education

\begin{tabular}{|c|c|c|}
\hline Last Education & Frequency (people) & Percentage (\%) \\
\hline Bachelor & 0 & - \\
\hline S2 & 43 & 23 \\
\hline S3 & 14 & 8 \\
\hline Professor & 5 & 100 \\
\hline Amount & 62 & 09 \\
\hline
\end{tabular}

Source: Primary Data processed in 2017

Based on the data in table 4, it shows that of 62 lecturers who become the sample in this study, it is dominated by S2 education that is 43 people or $69 \%$, S3 as many as 14 people or 23\%, undergraduate as much as zero person, while professors only amounted to 5 people or $8 \%$. However, it can be concluded that most lecturers of the Faculty of Economics of Makassar State University are educated (S2).

\section{DESCRIPTION OF RESEARCH VARIABLES}

To see the responses of respondents to the indicators and also the calculation of scores for the variables in detail can be seen as follows:

\subsection{Respondents Response against Variable Style of Transformational Leadership (X)}

Analysis of respondent's description of the variables of Transformational Leadership Style is based on the respondent's answers to the statements as contained in the questionnaires distributed to the respondents. Variations of respondents' answers can be seen in the table below 
The Effect of Transformational Leadership Style toward Lecturers Performance on Faculty of Economics of Makassar State University

Table5. Response of respondents regarding leadership style

\begin{tabular}{|c|c|c|c|c|c|c|c|c|c|c|c|c|}
\hline \multirow{3}{*}{$\mathrm{Nu}$} & \multirow{3}{*}{ Question } & \multicolumn{10}{|c|}{ Score } & \multirow{3}{*}{ Amount } \\
\hline & & \multicolumn{2}{|c|}{$\mathrm{V}(5)$} & \multicolumn{2}{|c|}{ A (4) } & \multicolumn{2}{|c|}{$\mathrm{LA}(3)$} & \multicolumn{2}{|c|}{ NA(2) } & \multicolumn{2}{|c|}{ VNA(1) } & \\
\hline & & $\mathrm{F}$ & $\%$ & $\mathrm{~F}$ & $\%$ & $\mathrm{~F}$ & $\%$ & $\mathrm{~F}$ & $\%$ & $\mathrm{~F}$ & $\%$ & \\
\hline 1 & $\begin{array}{l}\text { My leader when in making decis ions } \\
\text { always hold firm moral valu es and } \\
\text { rules that apply. }\end{array}$ & 18 & 29 & 43 & 69 & 1 & 2 & - & - & - & - & 265 \\
\hline 2 & $\begin{array}{l}\text { My leader has an idealistic char acter } \\
\text { and has strong confidence to carry out } \\
\text { the vision \& mission of the institution. }\end{array}$ & 18 & 29 & 43 & 69 & 1 & 2 & - & - & - & - & 265 \\
\hline 3 & $\begin{array}{l}\text { In carrying out my duties, my leadership } \\
\text { always attaches impor tance to the } \\
\text { improvement of the achievement of his } \\
\text { subordinates. }\end{array}$ & 15 & 24 & 47 & 76 & - & - & - & - & - & - & 263 \\
\hline 4 & $\begin{array}{l}\text { In performing my duties, my boss } \\
\text { always identified my needs as a } \\
\text { subordinate. }\end{array}$ & 24 & 39 & 38 & 61 & - & - & - & - & - & - & 272 \\
\hline 5 & $\begin{array}{l}\text { My leadership tends to show tan gible } \\
\text { results that can inspire his subordinates. }\end{array}$ & 21 & 34 & 40 & 65 & 1 & 2 & - & - & - & - & 268 \\
\hline 6 & $\begin{array}{l}\text { My leaders not only give instruct ions, } \\
\text { but participate in the exec ution of a job. }\end{array}$ & 16 & 26 & 46 & 74 & - & - & - & - & - & - & 264 \\
\hline 7 & $\begin{array}{l}\text { My leader is always trying to encourage } \\
\text { subordinates to rethink how to work and } \\
\text { find new ways of working in the field of } \\
\text { exper tise. }\end{array}$ & 22 & 35 & 38 & 61 & 2 & 3 & - & - & - & - & 268 \\
\hline 8 & $\begin{array}{l}\text { My leader always encour ages his } \\
\text { subordinates to alwaysdevelop their } \\
\text { knowledge / skills }\end{array}$ & 20 & 32 & 42 & 68 & - & - & - & - & - & - & 268 \\
\hline 9 & $\begin{array}{l}\text { My leadership has a strong chari sma in } \\
\text { leading his subordinates. }\end{array}$ & 23 & 37 & 39 & 63 & - & - & - & - & - & - & 271 \\
\hline 10 & $\begin{array}{l}\text { I support my leadership in reali zing } \\
\text { organizational goals because my leader } \\
\text { has a strong character. }\end{array}$ & 16 & 26 & 46 & 74 & - & - & - & - & - & - & 264 \\
\hline
\end{tabular}

Source: Primary Data processed in 2017

From the results seen in table 5, showing the responses of respondents to the statement on the transformational leadership style variables $(X)$ the highest value of the respondent's answer found in the fourth statement is "In carrying out the task, my boss always identifies my needs as subordinates" 272. While the lowest score is in the 3rd statement "In performing my duties, my boss always attaches importance to his subordinate achievement" to the number of 263, as for the question with the same number of questions 5, 7 and 8, This means the leaders in Faculty of Economics UNM always take into account when there is the need of subordinates, which resulted in the lack of attention to the process of subordinate increase, but the leadership is more likely to provide motivation and direction directly to subordinates.

\subsection{Results of Respondents against Lecturer Performance Variables (Y)}

The result of $\mathrm{Y}$ variable obtained from the results of data processing Performance Appraisal of Civil Servants (PPKP) by calculating the value of intervals or the average value of each lecturer at the Faculty of Economics, State University of Makassar.

\section{VALIDITY TEST}

The validity test is used to test the extent to which the precision of the measuring instrument can use the concept of a measured phenomenon or event. Validity test is used to measure whether or not a questioner is valid, a questionnaire is said to be valid if the statement or item on the questionnaire is able to reveal something that will be measured by the questionnaire. Validity test is calculated by comparing $r$ table value, if $r$ arithmetic $>$ from $r$ table (at significance level 5\%) then the statement is declared valid. 
Based on testing of data if using SPSS (Statistical Product Standard Solution) computer program 13.0 for windows, then obtained $r$ count $>$ from $r$ table $=0,227(r$ table value for $n=62)$. So all indicators of this research variable is valid.

\section{REABILITY TEST}

Reliability test is a tool to measure a questionnaire that is an indicator of a variable or construct. A questionnaire is said to be reliable or reliable if one's response to a statement is consistent or stable over time. Testing reliability in this research is to use alpha formula. Test results of reliability for each variable obtained data as follows:

Table6. Reliability Test Results

\begin{tabular}{|c|c|c|}
\hline Variable & Alpha Cronbach Calculate Value & Information \\
\hline Transformational Leadership Style & 0,583 & Reliabel \\
\hline
\end{tabular}

Source: Processed SPSS Data 2015

The results of reliability testing in table 6 shows all variables in the study have coefficient cronbach's alpha $(\alpha)$ is greater than 0.60 so it can be said all the concepts of variable measuring of the questionnaire is reliable which means that the questionnaire used in this study is a reliable questionnaire.

\section{Determination CoefFicient Analysis}

Table7. Correlation and Determinant Coefficients

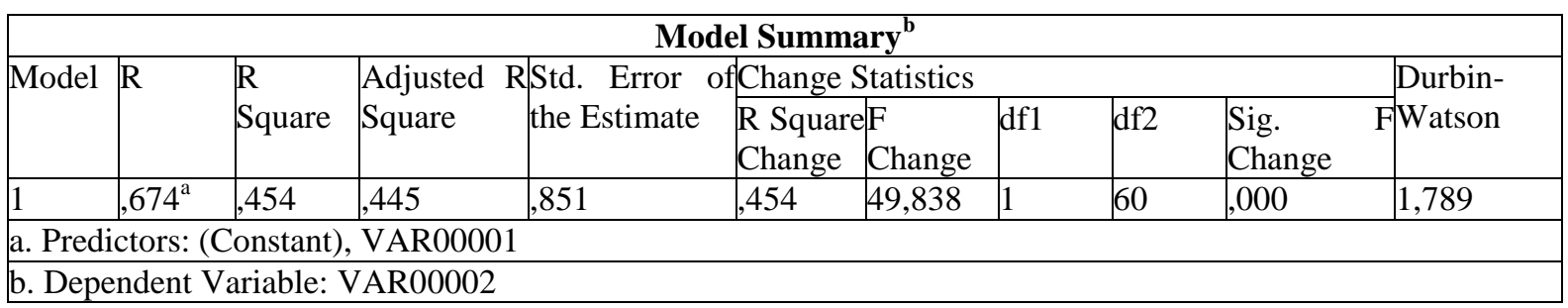

Classification of correlation coefficients used where the correlation values can be grouped in Nugroho, (2005: 18) as follows: $0.041-0.70$ correlation strong closeness, $0.71-0.09$ is very strong and 0.91- 0.99 is very strong and if 1 means perfect.

In the summary of results shown in the table above, the correlation coefficient $(\mathrm{R})=0.674$ or 0.67 means there is a positive relationship between the Transformational Leadership Style on Lecturer Performance at the Faculty of Economics, Makassar State University.

Table 7 also shows that the coefficient of determination (R square) used to calculate the indevendent influence ( $\mathrm{X}$ on the dependent variable $\mathrm{Y}$ ) is 0.454 or $45.4 \%$. This means that as much as $45.4 \%$ of lecturer's performance is influenced by transformational leadership style while $54.6 \%$ is influenced by other factors not examined.

\section{Simple Regression AnAlysis}

Linear regression is a statistical method used to establish the relationship between the dependent variable and the independent variable. If the number of independent variables is only one, then it can use simple linear regression.

The general form of simple linear regression is as follows:

$$
\mathbf{Y}=\boldsymbol{a}+\boldsymbol{b X}
$$

Where:

$\mathrm{Y}=$ Lecturer Performance (dependent variabl

$\mathrm{X}=$ Transformational Leadership Style (independent variable)

$\mathrm{a}=$ Intercept value (constant)

$\mathrm{b}=$ regression direction coefficient

Based on data analysis using simple regression calculation with IMB Statistical for Product and Service Solution (SPSS) program version 13.0 then got result as follows: 
The Effect of Transformational Leadership Style toward Lecturers Performance on Faculty of Economics of Makassar State University

Table8. Simple Regression Analysis

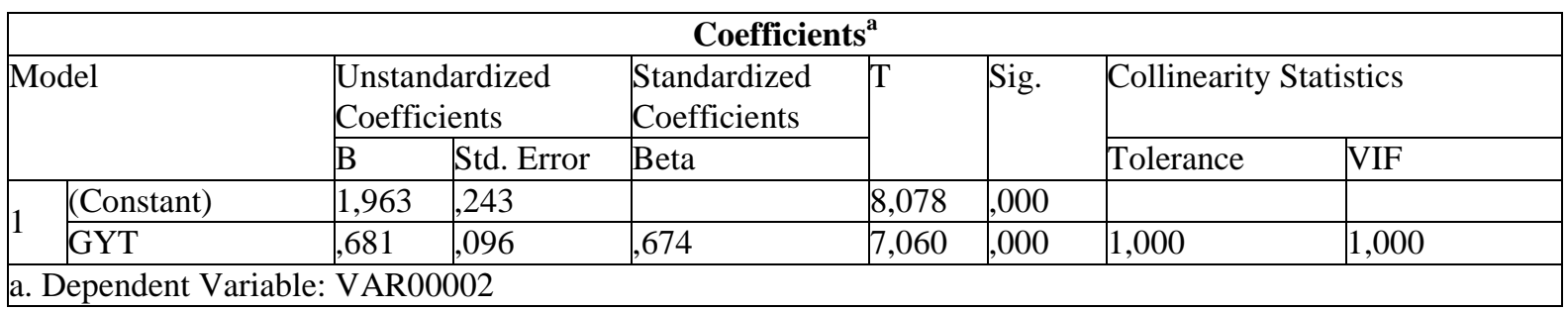

Source: print data processed in 2015 with SPSS 13.0

Based on the results of primary data processing on the results of simple regression in table 8 can be seen the regression equation as follows:

$$
\mathrm{Y}=1,963+0,681 \mathrm{e}
$$

\subsection{The Interpretation of the Regression Equation is}

a. Constant value equal to 1,963 means lecturer performance Faculty Economics of University of Neger Makassar equal to 1,963 unit, assuming transformational leadership style in constant or fixed state.

b. The value of regression coefficient of transformational leadership style variables of 0.681 with a significant level of 0.00 is smaller than $(<0.05)$. This result proves that the performance of lecturers will directly increase by 0.681 if the transformational leadership style at the Faculty of Economics, State University of Makassar 1\%. Coefficient of positive value means there is a positive relationship between transformational leadership style with lecturer performance.

\subsection{T Test}

The t-test is used to find out how far the partial influence of the independent variable is the transformational leadership style on the lecturer's performance. Through Testing can also be known about the information about how much influence of independent variables on lecturer performance. By using the sample of 62 people with $\mathrm{df}=\mathrm{n}-2$ or $\mathrm{df}=62-2=60$ then, obtained $\mathrm{t}_{\text {table }}(1,670)$ with significance level $>(\alpha) 0,05$. Based on table 12 above, the calculation results obtained as follows:

Variable Transformational Leadership Style with $t$ _hitung $(7.060)>t_{\text {table }}(1,670)$ with significance level of 0.00 which means $\mathrm{H}_{1}$ accepted and $\mathrm{H}_{0}$ rejected. That is, there is a significant influence between the Transformational Leadership Style on Lecturer Performance.

Transformational Leadership Style partially have a positive and significant impact on Lecturer Performance. Based on t-test results can be concluded that the hypothesis in this study can be accepted.

\section{DisCuSSION}

The application of Transformational Leadership Style has theoretically influenced the performance of lecturers. The achievement of agency targets, the realization of the vision and mission of the institution, the realization of work environment and the familiarity between the employees are most of the factors that determine the success of the institution in maintaining and improving the performance, both for the department and university level.

The Leader of the Faculty of Economics of Makassar State University has done various ways to improve lecturers' performance so that the agency's productivity will be sustainable and can increase according to the target. In accordance with the observational understanding of researchers that the application of Transformational Leadership Style is something that needs to be paid attention by educational institutions, because the Transformational Leadership Style is expected to create a harmonious relationship between the leadership and subordinates (lecturers). This will certainly affect the performance of subordinates (lecturers).

Variable X (Transformational Leadership Style), based on research that has been done research has a positive and significant influence on variable Y (Lecturer Performance) Faculty of Economics, State University of Makassar. 
The conclusion of the discussion of the results of research has been done that there is a significant and positive influence between the Transformational Leadership Style on Lecturer Performance. This is supported by some experts as follows:

According to Bass in Swandari (2003) "Transformational leadership has the power to influence subordinates in certain ways. With the application of subordinate transformational leadership will feel trusted, appreciated, loyal and responsive to the leadership.

According to Kendra (2013) "The transformational leader is a leader who controls the situation by delivering a clear vision of group goals, passion in work and the ability to make group members feel recharged and energized".

Bass also adds that transformational leadership is how leaders change (to transform) the perceptions, attitudes, and behaviors of subordinates regardless of whether or not changes occur. Conceptually, transformational leadership (to transform) is as a leader's ability to change work environment, work motivation, work patterns, and work values of subordinates so that subordinates will further optimize performance to achieve organizational goals.

From the results of his research shows that the Transformational Leadership Style has a significant influence on Lecturer Performance at the Faculty of Economics, Makassar State University.

\section{CONCLUSION/RECOMMENDATION}

The conclusions obtained from the analysis of the problem, the results of data analysis up to the discussion are:

1. Transformational Leadership Style (X) has a positive effect on Lecturer Performance (Y). This is because the Transformational Leadership Style is applied as one way to improve the performance of lecturers, so that the lecturers can perform the assigned task well.

2. The amount of relationship between Transformational Leadership Style with Lecturer Performance Faculty of Economics, State University of Makassar is equal to 0.674 which is at a strong level. This is a lecturer after the implementation of transformational leadership style will be able to bring up innovations and methods in the learning process with good quality and efficiency.

3. Faculty of Economics Makassar State University should pay more attention to the application of leadership style of each leader, so that every subordinate can carry out their duties ideally so as to present the performance of lecturers according to the applicable rules.

4. With the significant influence in the application of Transformational Leadership Style (X) to Lecturer Performance (Y), it is expected that the leaders at Makassar State University are keener to choose the leadership style that will be applied so that the lecturers feel protected and feel no gap between the boss and subordinate.

\section{REFERENCES}

[1] Armstrong, Michael. 1994. Manajemen Sumber Daya Manusia: A Handbook Of Human

[2] Resource Management. PT Elex Media Komputindo. Jakarta.

[3] Avolio, B.J. \& Bass, B.M. (1994). Individual Consideration Viewed at MultipleLevels of Analysis: A Multilevel Framwork for Examining Te Diffusio of Transformational Leader ship. Journal of Leadership Quarterly. 6(2), 199-218.

[4] Bass, B.M (1985). Leadership and Performance beyond Expectation, New York: Free Press.

[5] Bass, B.M., Avolio, B.J. (1994). Improving Organizational Effect iveness through Transfor masional Leadership.Thousand oaks: Sage Dale, Robert. D. 1992. Pelayan Sebagai Pemimpin. Gandum Mas. Malang.

[6] Burns, J.M. (1978).Leadership New York: Harper \& Row.

[7] Guritno, Bambang dan Waridin. 2005. Pengaruh Persepsi Karyawan Mengenai Perilaku Kepemimpinan, Kepuasan Kerja Dan Motivasi Terhadap Kinerja. JRBI.Vol 1. No 1. Hal: 63-74.

[8] Hasibuan, Malayu S.P. 2004. Manajemen Sumber Daya Manusia. PT. Bumi Aksara. Jakarta.

[9] Hasibuan, Malayu S.P. 2008. Manajemen Sumber Daya Manusia. PT. Bumi Aksara. Jakarta.

[10] Hasibuan, Malayu S.P. 2011. Manajemen Dasar, Pengertian, dan Masalah. PT. Bumi Aksara. Jakarta. 
The Effect of Transformational Leadership Style toward Lecturers Performance on Faculty of Economics of Makassar State University

[11] Keller, R.L. (1992).Transformasional Leadership and the Performance of Research and Development Project Groups. Journal of Management,18(3):489-501

[12] Malthis, L. Robert dan Jackson. H. John, 2001. Manajemen Sumber Daya Manusia, Edisi Pertama, Buku I. PT. Salemba Empat, Jakarta.

[13] Malthis, L. Robert dan Jackson. 2001. Manajemen Sumber Daya Manusia. PT. Salemba Empat. Jakarta.

[14] Riduwa, dan Sunarto, 2010, Pengantar Statistika, Untuk Penelitian Pendidikan, Sosial, Ekonomi Komunikasi, dan Bisnis, Penerbit: Alfabeta, Bandung.

[15] Rivai, Veithzal dan Ahmad Fawzi Mohd Basri. 2005. Performance Appraisal. Cetakan Pertama. PT. Raja Grafindo Persada. Jakarta.

[16] Robbins, Stephen. P. dan Mary Coulter. 2005. Manajemen. PT.Index Kelompok Gramedia, Jakarta.

[17] Robbins, Stephen. P. 2006. Perilaku Organisasi. Edisi Bahasa Indonesia. PT. Index Kelompok Gramedia. Jakarta.

[18] Setiyawan, Budi \& Waridin. 2006. Pengaruh Disiplin Kerja Karyawan dan Budaya Organisasi Terhadap Kinerja di Divisi Radiologi RSUP Dokter Kariadi, Semarang: JRBI. Vol 2. No 2.

[19] Siagian, Sondong. P. 2002. Kiat Meningkatkan Produktivitas Kerja. PT. Rineka Cipta. Jakarta.

[20] Soetjipto, Budi W. 2004. Paradigma Baru Manajemen Sumber Daya Manusia. Penerbit Amara Books, Yogyakarta.

[21] Terry, R George. 2006. Prinsip-prinsip Manajemen. Penerbit PT Bumi Aksara, Jakarta.

\section{AUTHOR's BIOGRAPHY}

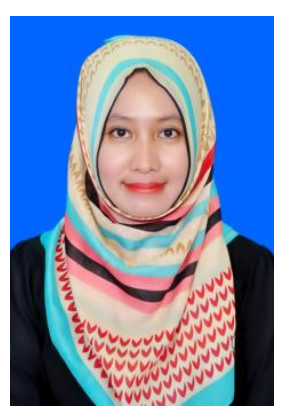

Asni, is the Head of Department of Management Programs STIMI-YAPMIM Makassar, South Sulawesi, Indonesia.

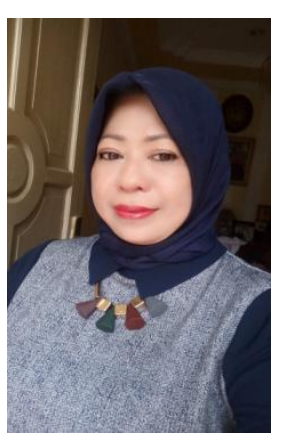

Nursia, She is the lecturer of Department of Management Programs STIMIYAPMIM Makassar, South Sulawesi, Indonesia.

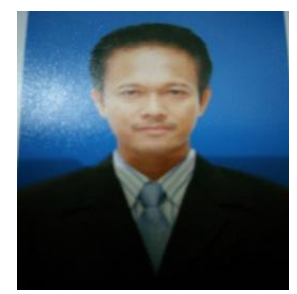

Anwar Ramli, He is the lecturer of Department of Management, Faculty of Economy, State University of Makassar, South Sulawesi, Indonesia 